\title{
Development of Avinit duplex technology to increase the wear resistance of the gearbox separator
}

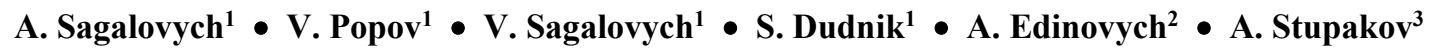

Received: 10 August 2020 / Accepted: 24 November 2020

\begin{abstract}
The Avinit duplex technology has been developed by means of plasma precision nitriding of Avinit $N$ and the subsequent application of a multifunctional antifriction coating Avinit $C$ on the surfaces of rubbing bodies and perceives power loads.

The influence of the duplex process on the dimensions of the parts was investigated; the properties of the nitrided layer and the parameters of Avinit coatings were studied. Avinit duplex technology ensures the application of highly adherent, high-quality multifunctional anti-friction wear-resistant Avinit C coatings on complex-profile parts. Using the developed Avinit duplex technology, a pilot batch of separators for the freewheel of the main gearbox of the helicopter was manufactured. All parameters of the separator, manufactured using the Avinit duplex technology, fully comply with the technical, metallurgical and metallographic requirements of design documentation (thickness and microstructure of the nitrided layer, no brittleness, thickness and hardness of the coating, preservation of geometric parameters with an accuracy of 0.5 microns). The Avinit coated freewheel separator has been successfully tested as part of the main gearbox for a helicopter at a full-scale stand. As shown by the test results, the use of the developed Avinit duplex technology ensures the complete absence of fretting wear of the working surfaces, which is common for serial separators.
\end{abstract}

Keywords: development of Avinit duplex technology, properties of the nitrided layer, characteristics of coatings, bench tests of separators.

\section{Introduction}

Defects of free wheel units (FWU) have been observed in MI-2 helicopters from the beginning of their flight operation. These defects are explained mainly by severe fretting wear of the friction surfaces.

The most vulnerable responsible element is the separator, i.e. free wheel units that transmit torque from the engine to the main gearbox, and is designed for uniform distribution of rolling elements (rollers) and the direction of their movement.

In order to increase the efficiency of FWU elements of the main gearbox BP-2, special coatings were developed for separator. It is known that separator of gearboxes

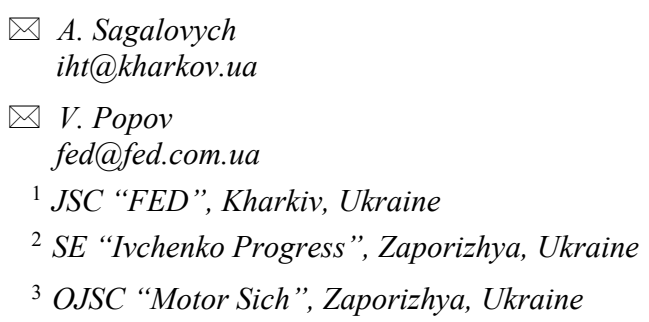

${ }^{3}$ OJSC "Motor Sich”, Zaporizhya, Ukraine

BP-8A, BP-14 are covered with polytetrafluorethylene by electrophoretic method in order to reduce fretting wear [1].

Due to critical disadvantages of the electrophoresis process, it was proposed to use antifriction coatings $\boldsymbol{A v i n i t}$ $[2,3]$, developed by JSC "FED" and STC "Nanotechnology", Kharkiv city.

Studies [4-6] have confirmed the high antifriction properties of Avinit $\mathrm{C}$ coating when applied to critical parts in machinery industry. Coatings Avinit C310 and Avinit C320 are successfully used in the spools of hydraulic units manufactured by JSC FED, which, in particular, has increased the life of the units in $2 \ldots 3$ times $[2,3]$.

In order to determine the possibilities of applying Avinit coating, SE "Ivchenko-Progress" and PJSC "Motor Sich" together with JSC FED and STC "Nanotechnology" carried out researches [7,8] and came to conclusion on possibility for use of in aircraft gearboxes.

JSC FED and STC "Nanotechnology" have developed complex duplex technologies Avinit [9], including plasma nitriding and ion-plasma application of wear-resistant coatings in a single process.

Due to the absence of a brittle layer on the nitrided surface after precision nitriding, retaining the original geo- 
metric dimensions that do not require further mechanical rework, and compatibility of the processes of plasma precision nitriding Avinit $\mathrm{N}$ and vacuum-plasma application of Avinite functional coatings, duplex technologies Avinit allows application of highly adhered, high-quality strengthening antifriction coating Avinit.

Developed complex duplex technologies Avinit were used in manufacture of full-size high-precision parts of gear wheels of 4 th accuracy degree [9].

A pair of experimental gears 4501150003-02 and 4501150004-01, reinforced by duplex technology Avinit and installed in the gearbox of the AI- $450 \mathrm{M}$ engine instead of serial wheels of the second stage of the gearbox, has successfully passed field tests as a part of AI-450M engine gearbox on the hydraulic brake stand at SE "Ivchenko-Progress" according to the program of equivalent-cyclic tests within 26 hours.

Changes in the geometry of the teeth of the wheel and wear of the coating Avinit $\boldsymbol{C}$ was not detected after test.

The purpose of this work is to test Avinit duplex technology on complex parts in order to increase the wear resistance of the separator by plasma precision nitriding Avinit $N$ and subsequent application of antifriction coating Avinit C320 on friction surfaces and surfaces that receive force loads ("windows" and bore diameters). To study the increase in wear resistance of the gearbox separator, PJSC "Motor Sich" has manufactures test batch of separators BP42121226 for FWU of gearbox BP-442 [10] for further use of duplex technology Avinit with coating Avinit C320 [11].

Separator material is steel $38 \mathrm{X} 2 \mathrm{MHA-Ш,} \mathrm{hardness}$ of the base is $27.0 \ldots 38.5 \mathrm{HRC}$, operating conditions: airlubricating medium at a temperature of $+90^{\circ} \mathrm{C}$.

Technical requirements to application of Avinit C320 coating.

1. The thickness of the coating is no more than 2-3 microns. Circular application is acceptable.

2. Part temperature during application of coating should not exceed $300{ }^{\circ} \mathrm{C}$.

3. One separator (process) is designed to test the technology and subsequent metallurgical research (fig. 1).

4. The second separator with applied coating is intended for use in main gearbox for the purpose of field tests. Separators were subject to chemical and thermal treatment and covered with antifriction coating by duplex technology Avinit.

One of separators was subject to metallurgical study in order to determine quality of plasma nitriding and Avinit coating (fig. 2).

Measurements of microhardness along the depth of the nitrided layer show that the nitrided layer is evenly distributed over the entire surface of the separator, the effective depth of the nitrided layer corresponding to $447 \mathrm{HV}$ (at groove face b) and $451 \mathrm{HV}$ (at Ø 52) is equal to $0.2 \mathrm{~mm}$ (table 1).

Based on the micro-measurements of nominal dimensions of the separator before and after coating with
Avinit C320, it was found that the layer thickness is stable, uniform and is equal to $1-2 \mu \mathrm{m}, \mathrm{H} \mu=3000$. The quality of adhesion of the coating with the part is satisfactory and there are no signs of peeling.

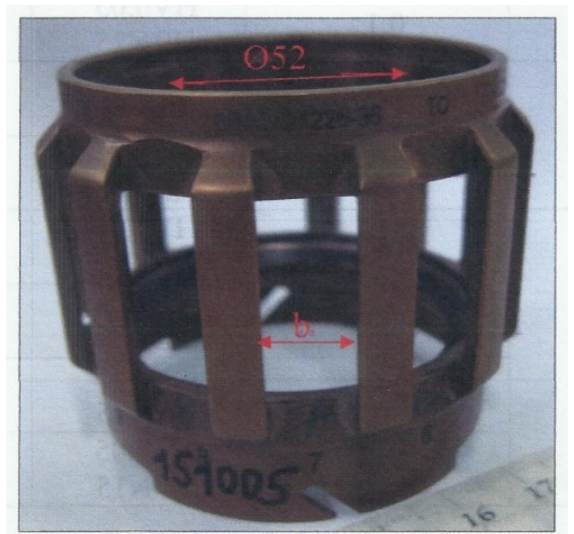

Fig. 1. Appearance of process separator with Avinit $\mathrm{C} 32$ coating

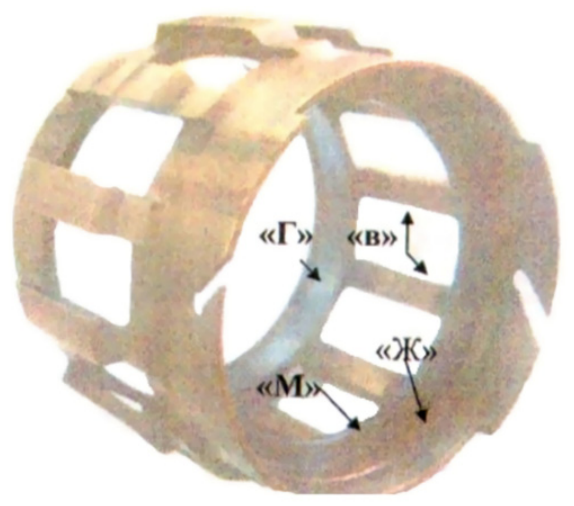

Fig. 2. Scheme of metallurgical measurements of separator

Table 1.

\begin{tabular}{|c|c|c|c|}
\hline \multirow{2}{*}{$\begin{array}{c}\text { Area } \\
\text { name }\end{array}$} & $\begin{array}{c}\text { Distance } \\
\text { from the sur- } \\
\text { face, mm }\end{array}$ & $\begin{array}{c}\text { Measurement } \\
\text { units }\end{array}$ & $\begin{array}{c}\text { Microhardness } \\
\text { along cross section } \\
\text { of sample }\end{array}$ \\
\hline \multirow{4}{*}{$\begin{array}{c}\text { Groove } \\
\text { face b }\end{array}$} & 0.1 & $\begin{array}{c}\text { HV0.05 } \\
\text { HRC15 }\end{array}$ & 799 \\
& 0.2 & HV0.05 & 91.5 \\
\cline { 2 - 4 } & 0.3 & HVC15 & 847 \\
& & HRC15 & 33.0 \\
\hline \multirow{4}{*}{$\varnothing 52$} & 0.1 & HV0.05 & 78.5 \\
\cline { 2 - 4 } & 0.2 & HRC15 & 91.0 \\
\cline { 2 - 4 } & & HV0.05 & 451 \\
& 0.3 & HRC15 & 83.0 \\
\cline { 2 - 4 } & 0.4 & HV0.05 & 408 \\
& & HRC15 & 81.0 \\
\hline
\end{tabular}


Results of measurement of hardness, depth of nitrided layer as well as thickness of antifriction coating $\mathbf{A v i -}$ nit are shown in table 2.

Table 2.

\begin{tabular}{|c|c|c|c|c|c|}
\hline \multirow{2}{*}{$\begin{array}{l}\text { Area } \\
\text { name }\end{array}$} & \multicolumn{3}{|c|}{ Hardness } & \multirow{2}{*}{$\begin{array}{c}\text { Dept } \\
\mathrm{h} \text { of } \\
\text { ni- } \\
\text { tride } \\
\mathrm{d} \\
\text { layer, } \\
\mathrm{mm}\end{array}$} & \multirow{2}{*}{$\begin{array}{c}\text { Thickness } \\
\text { of coating } \\
\text { Avinit } \\
\text { C320, mm }\end{array}$} \\
\hline & $\begin{array}{c}\text { Coating } \\
\text { Avinit } \\
\text { C320, } \\
\text { HV0,05 }\end{array}$ & $\begin{array}{l}\text { nitrided } \\
\text { surfaces } \\
\text { HRN15 }\end{array}$ & $\begin{array}{c}\text { Bases, } \\
\text { HRC }\end{array}$ & & \\
\hline $\begin{array}{c}\text { Groove } \\
\text { face }\end{array}$ & $1042 \ldots 1124$ & $92,0 \ldots 93$ & \multirow{2}{*}{35} & 0,2 & $0,001 \ldots 0,002$ \\
\hline Ø 52 & & 91 & & 0,2 & 0,001 \\
\hline \begin{tabular}{|c|c}
$\mathrm{TD}$ \\
norms
\end{tabular} & & $\geq 83$ & $27,0 \ldots 38,5$ & 0,2 & $0,001 \ldots 0,002$ \\
\hline
\end{tabular}

The microstructure of the nitrided layer (fig. 3, 4) is satisfactory and represented by martensite + nitrides, the bases are low-carbon martensite, which is typical for steel 38X2MЮA, heat-treated for given hardness.

All parameters of the separator made by duplex technology Avinit (plasma precision nitriding Avinit N + application of superhard antifriction coating Avinit C320) fully meet the technical, metallurgical and metallographic requirements of CD (thickness and microstructure of the nitrided layer etc., parameters are saved) [1] (fig. 5, 6).

The appearance of separators with antifriction coating Avinit C320 is shown in fig. 7.

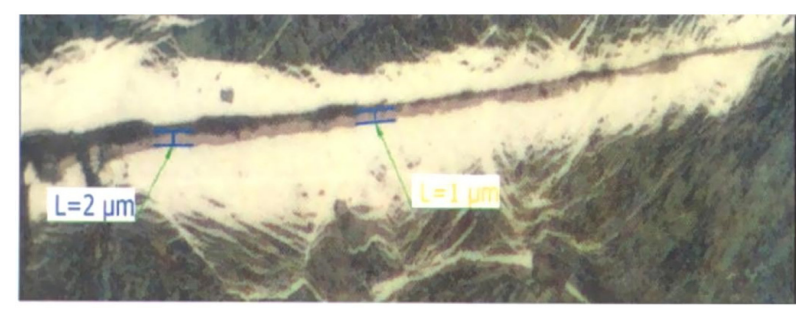

$a$
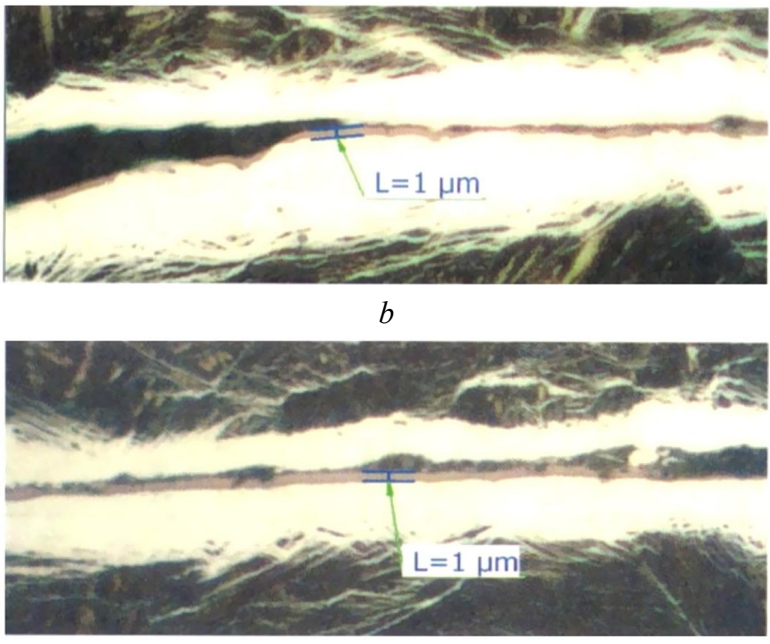

$c$

Fig. 3. Microstructure of nitrided layer with coating Avinit C320 x 1000

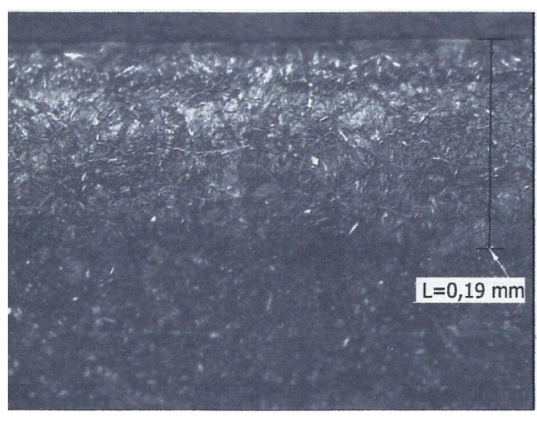

$a$

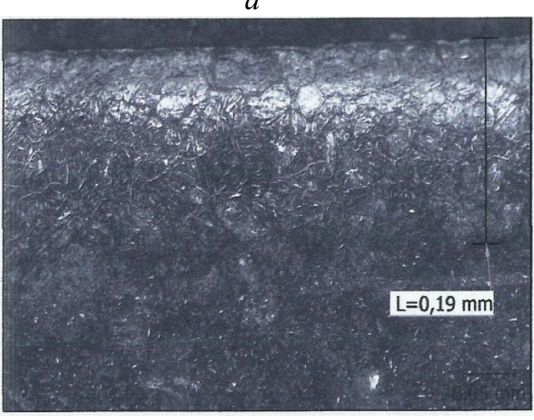

$b$

Fig. 4. Microstructure of nitrided layer $\mathrm{x} 200 \mathrm{a}$ - groove face $b-\varnothing 52$
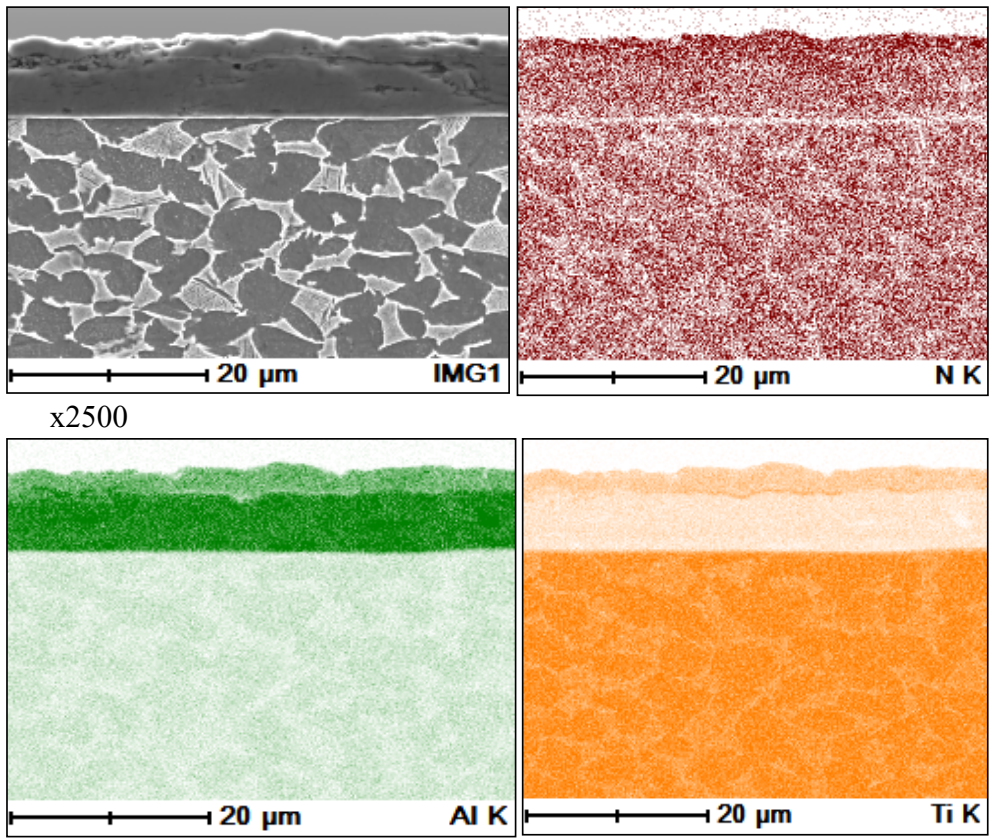

Fig. 5. Appearance of Ti-Al-N coating (cross section) in mapping mode. 


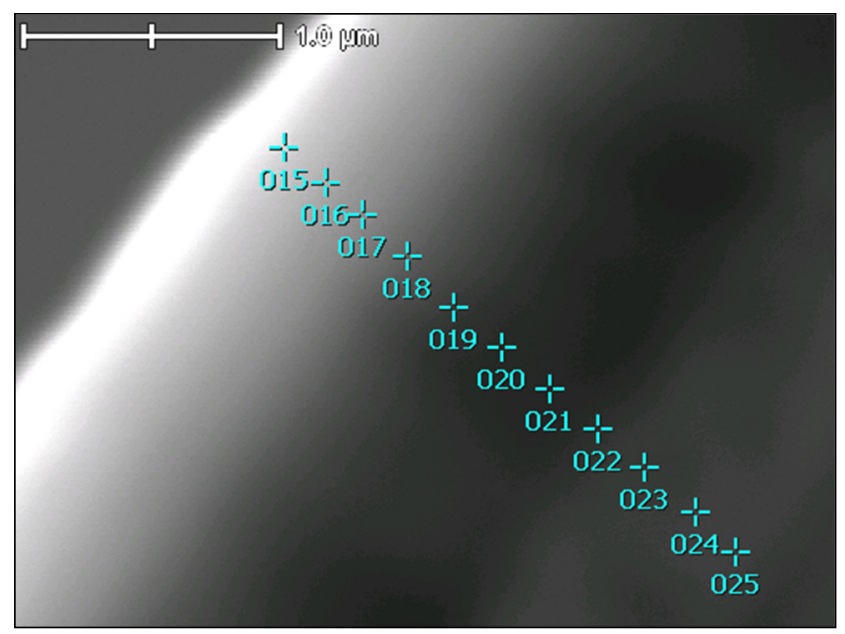

$\mathrm{x} 40000$

\begin{tabular}{|c|c|c|c|c|c|c|c|}
\hline $\begin{array}{c}\text { No. } \\
\text { Point }\end{array}$ & $\mathrm{N}$ & $\mathrm{Al}$ & $\mathrm{Si}$ & $\mathrm{Ti}$ & $\mathrm{Cr}$ & $\mathrm{Fe}$ & $\begin{array}{c}\text { Total, } \\
\%\end{array}$ \\
\hline 015 & 4.39 & 14.18 & & 81.43 & & & 100 \\
\hline 016 & 5.27 & 30.68 & & 64.04 & & & 100 \\
\hline 017 & 3.31 & 38.82 & & 57.87 & & & 100 \\
\hline 018 & 2.60 & 15.38 & & 82.01 & & & 100 \\
\hline 019 & 1.31 & 7.02 & & 91.67 & & & 100 \\
\hline 020 & 1.10 & 4.48 & & 91.96 & & 2.46 & 100 \\
\hline 021 & 1.24 & 3.29 & & 87.10 & & 8.37 & 100 \\
\hline 022 & 0.10 & 1.50 & & 64.97 & 6.31 & 27.12 & 100 \\
\hline 023 & & & 0.32 & 24.44 & 10.56 & 64.68 & 100 \\
\hline 024 & & & 0.48 & 7.01 & 11.61 & 80.89 & 100 \\
\hline 025 & & & 0.59 & 4.90 & 11.78 & 82.74 & 100 \\
\hline
\end{tabular}

$b$

Fig. 6. Appearance of Ti-Al-N coating (transverse section) with the indicated analyzed areas $-a$, approximate chemical composition of the analyzed areas $-b$. Coating thickness $\sim 1,5$ мкм

The appearance of separators with antifriction coating Avinit $\mathrm{C} 320$ is shown in fig. 7.

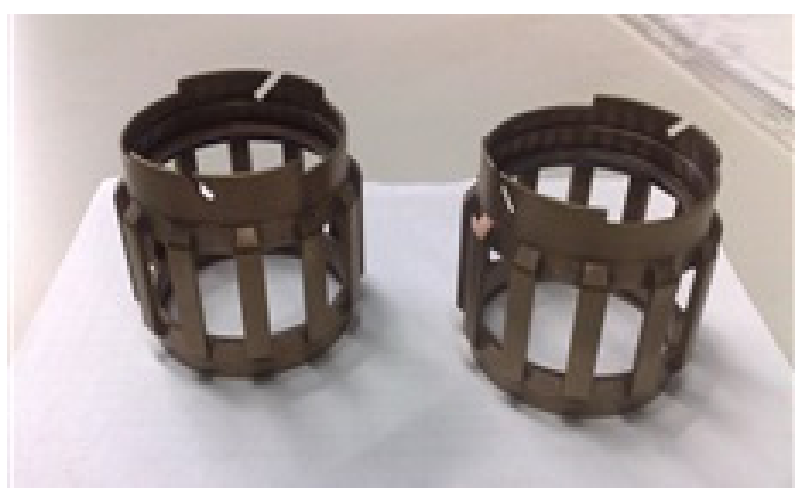

Fig. 7. Appearance of separators with antifriction coating Avinit C320

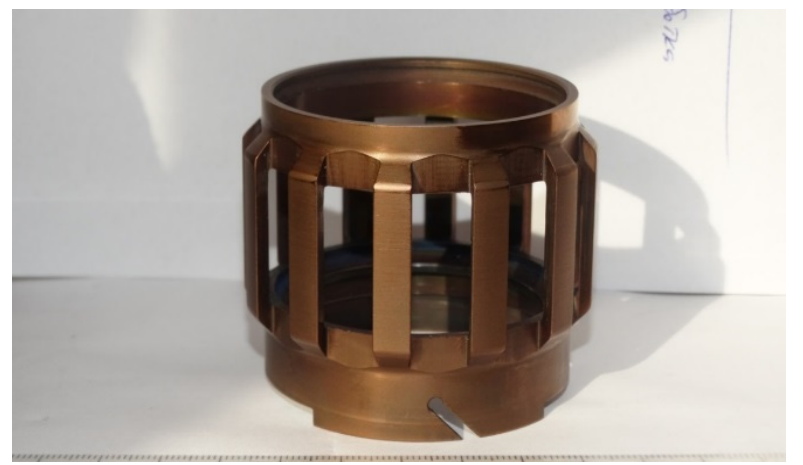

Fig. 8. Separator (nitriding of Avinit $\mathrm{N}+$ Avinit C C320 coating) after tests
FWU separator (free wheel unit) coated with Avinit C320 was tested as part of the main gearbox on a full-scale stand [11] (fig. 8).

Test results show that Avinit plasma nitriding in combination with the subsequent application of Avinit C superhard coating prevents fretting wear of work surfaces, which is common for serial separators.

Separator with an Avinit C320 covering is recommended for serial production after carrying out technological tests in BP-442 main gearbox.

The separator coated with Avinit C320 and used in main reducer is subject to long-term tests on the fullscale stand and operational tests of the separator simultaneously with the modified main shaft as a part of the helicopter.

\section{Conclusions}

1. Developed duplex technology Avinit for plasma precision nitriding Avinit $\mathrm{N}$ and subsequent application of multifunctional antifriction coating Avinit C on friction surfaces and surfaces that receive force loads ("windows" and bore diameters) on complex parts (separator).

Avinit duplex technology ensures the application of highly adhered, high-quality strengthening antifriction coatings Avinit C on complex open details.

2. Test batch of separators BP42121226 for free wheel unit (FWU) of main gearbox BP-442 was manufactured using the developed duplex technology Avinit (plasma nitriding Avinit $\mathrm{N}+$ vacuum-plasma coating Avinit C320).

All parameters of the separator, made by duplex technology Avinit, fully meet the technical, metallurgical 
and metallographic requirements of CD (thickness and microstructure of the nitrided layer, absence of fragility, etc., thickness and hardness of the coating, preservation of geometric parameters with an accuracy of $0.5 \mu \mathrm{m})$.

3. Free wheel unit separator coated with Avinit C320 has been tested as part of helicopter main gearbox on a fullscale stand.
Test results show that the use of the developed duplex technology Avinit ensures the complete absence of fretting wear of work surfaces that is common for serial separators.

\section{References}

[1] K.-J. Bathe, Finite Element Procedures, 2nd ed., K.-J. Bathe, Watertown: MA, 2016. https://doi.org/10.1201/9781315641645-2

[2] N.G. Afendikova, "Istoriya metoda Galerkina i ego rol'v tvorchestve M.V. Keldysha", Preprinty IPM im. M.V. Keldysha, no. 77, pp. 3-17, 2014. http://library.keldysh.ru/preprint.asp?id=2014-77

[3] S.P. Demidov, Teoriya uprugosti [Theory of elasticity], "Vyssha shkola", Moscow, Russia, 1979.

[4] C.A.J. Fletcher, Computational Galerkin methods, New-York: Springer-Verlag, 1984. https://doi.org/10.1007/978-3-64285949-6

[5] S.P. Timoshenko and S. Woinowsky-Krieger, Theory of plates and shells, 2nd ed., New York: McGraw-Hill Inc., 1959.

[6] I. Elishakoff, A.P. Ankitha and A. Marzani, "Rigorous versus naïve implementation of the Galerkin method for stepped beams", Acta Mechanica, vol. 230, pp. 3861-3873, 2019. doi:https://doi.org/10.1007/s00707-019-02393-z

[7] G.B. Warburton, "The vibration of rectangular plates", Proc. Inst. Mech. Engrs., vol. 168, pp. 371-384. 1954. doi: https://doi.org/10.1243/PIME_PROC_1954_168_040_02

[8] P. Moreno-García, J.V. Araújo dos Santos and H. Lopes, "A review and study on Ritz method admissible functions with emphasis on buckling and free vibration of isotropic and anisotropic beams and plates", Archives of Computational Methods in Engineering, vol. 25, pp. 785-815, 2018. https://doi.org/10.1007/s11831-017-9214-7

[9] U. Lee, Spectral element method in structural dynamics, John Wiley and Sons (Asia), Singapore, 2009. https://doi.org/10.1002/9780470823767

[10] J.T.-S. Wangand C.-C. Lin, "Dynamic analysis of generally supported beams using Fourier series", Journal of Sound and Vibration, vol. 196, no. 3, pp. 285-293, 1996. https://doi.org/10.1006/jsvi.1996.0484

[11] S. Zhang, L. Xu and R. Li, "New exact series solutions for transverse vibration of rotationally-restrained orthotropic plates", Applied Mathematical Modeling, vol. 65, pp. 348-360, 2019. https://doi.org/10.1016/j.apm.2018.08.033

\section{Розробка дуплексної технології Avinit для підвищення зносостійкості сепа- ратора редуктора}

\section{О. В. Сагалович, В. В. Попов, В. В. Сагалович, С. Ф. Дуднік, А. Б. Сдинович, О. А Ступаков}

Анотація. Розроблена дуплексна технологія Аvinit иляхом плазмового прецизійного азотування Avіпіt $N$ i подальщого нанесення поліфункціонального антифрикційного покриття Avinit C на поверхні, ш⿻о труться $i$ сприймають силові навантаження.

Досліджено вплив дуплексного процесу на розміри деталей, вивчені властивості азотованого шару і параметри покриттів Avinit.

Дуплексна технологія Avinit забезпечує нанесення міцунозчеплених, високоякісних поліфункиіональних антифрикційних зносостійких покриттів Аvinit С на складнопрофільних деталях.

Із застосуванням розробленої дуплексної технологї̈ Аviпit виготовлена дослідна партія сепараторів для муфти вільного ходу головного редуктора гвинтокрила.

Всі параметри сепаратора, виготовленого за дуплексною технологією Аvіпіt, повністю відповідають технічним, металургійним і металографічним вимогам КД (товщина і мікроструктура азотованого шару, відсутність крихкості, товщина $і$ твердість покриття, збереження геометричних параметрів з точністю до 0,5 мкм).

Сепаратор муфти вільного ходу з покриттям Avinit успішно пройшов випробування в складі головного редуктора гвинтокрилу на натурному стенді.

Як показали результати випробувань, застосування розробленої дуплексної технологї Аvіпіt забезпечує повну відсутність фретинг-зносу робочих поверхонь, звичайного для серійних сепараторів.

Ключові слова: розробка дуплексної технологї̈ Avinit, властивості азотованого шару, характеристики покриттів, стендові випробування сепараторів. 


\title{
Разработка дуплексной технологии Avinit для повышения износостойкости сепаратора редуктора
}

\author{
А. В. Сагалович, В. В. Попов, В. В. Сагалович, С. Ф. Дудник, А. Б. Единович. А. А. Ступаков
}

Аннотация. Разработана дуплексная технология Avinit путем плазменного прецизионного азотирования Аvinit $N$ и последующего нанесения полифункиионального антифрикиионного покрытия Avinit C на поверхности трущихся и воспринимают силовые нагрузки.

Исследовано влияние дуплексного процесса на размеры деталей, изучены свойства азотированного слоя и параметры покрытий Avinit.

Дуплексная технология Avinit обеспечивает нанесение прочносцепленных, высококачественных полифункциональных антифрикиионных износостойких покрытий Avinit С на сложнопрофильных деталях.

С применением разработанной дуплексной технологии Аviпit изготовлена опьтная партия сепараторов для муфть свободного хода главного редуктора вертолета.

Все параметры сепаратора, изготовленного по дуплексной технологии Аvinit, полностью соответствуют техническим, металлургическим и металлографическим требованиям КД (толщина и микроструктура азотированного слоя, отсутствие хрупкости, толщина и твердость покрытия, сохранение геометрических параметров с точностью до 0,5 мкм).

Сепаратор муфты свободного хода с покрытием Аvinit успешно прошел испытания в составе главного редуктора вертолету на натурном стенде.

Как показали результаты испытаний, применение разработанной дуплексной технологии Аvіпіt обеспечивает полное отсутствие фреттинг-износа рабочих поверхностей, обычного для серийных сепараторов.

Ключевые слова: разработка дуплексной технологии Avinit, свойства азотированного слоя, характеристики покрытий, стендовые испытания сепараторов. 